\title{
Putative historical occurrence of North Atlantic right whales in mid-latitude offshore waters: ‘Maury's Smear' is likely apocryphal
}

\author{
Randall R. Reeves ${ }^{1, *}$, Elizabeth Josephson ${ }^{2}$, Tim D. Smith ${ }^{2}$ \\ ${ }^{1}$ Okapi Wildlife Associates, 27 Chandler Lane, Hudson, Quebec J0P 1H0, Canada \\ ${ }^{2}$ Northeast Fisheries Science Center, 166 Water Street, Woods Hole, Massachusetts 02543, USA
}

\begin{abstract}
The seasonal distribution of North Atlantic right whales Eubalaena glacialis is generally well known in coastal areas but poorly known in offshore portions of the species' range. Two main areas of offshore occurrence have been known or suspected, based largely on evidence from 19th century American whaling logbooks: the Cape Farewell Ground east and south-east of the southern tip of Greenland, and 'Maury's Smear', a mid-latitude area bounded by 35 to $43^{\circ} \mathrm{N}$ and 25 to $48^{\circ} \mathrm{W}$. While the modern occurrence of whales on the old Cape Farewell Ground has been demonstrated by recent sightings, this is not the case for Maury's Smear. Moreover, by examination of original sources we provide direct evidence that the offshore distribution illustrated by Maury in 1852 and 1853 was at least partly and possibly entirely erroneous, based on faulty data extraction and transcription procedures. Our results cast doubt on Maury's charts of 19th century whale distribution more generally, leading us specifically to question the reliability of his depictions of right whale occurrence in offshore portions of other ocean basins.
\end{abstract}

KEY WORDS: North Atlantic right whale $\cdot$ Eubalaena glacialis $\cdot$ Distribution · Matthew Fontaine Maury $\cdot$ North Atlantic Ocean

\section{INTRODUCTION}

The North Atlantic right whale Eubalaena glacialis was the first whale species to be hunted commercially. By approximately 1730 its numbers had become so reduced from whaling that it was no longer the principal target of most whaling operations. For the remainder of the 18th century and throughout the 19th century the focus of whaling operations in the North Atlantic shifted to sperm whales Physeter macrocephalus and, to a lesser extent, to humpback whales Megaptera novaeangliae, while right whales continued to be taken opportunistically. They were considered essentially extirpated in the western North Atlantic by the early 20th century, but Schevill (1959) announced 'the return of the right whale to New England waters' in the mid-1950s. His 'rediscovery' of the species was followed by a resurgence of scientific interest that continues to the present day (Watkins \& Schevill 1983, Kraus et al. 1986, Schevill et al. 1986, Katona \& Kraus 1999, Reeves 2001, Reeves \& Kenney 2003). A population of 300 to 350 right whales persists along the eastern North American coast, but only scattered and occasional observations of the species have been made in European waters since the early 1900s, when about 135 individuals were taken at shore whaling stations from Iceland to the British Isles (Brown 1986).

Although 2 winter calving grounds were known historically - one off north-western Africa and the other off the American coast between northern Florida and South Carolina - only the latter appears to be used by right whales today (Reeves \& Mitchell 1986, 1988, Notarbartolo di Sciara et al. 1998). Whales wintering along the south-eastern coast of the United States constitute only a portion of the total population in any 
given year (Brown et al. 2001). They migrate northward along the American coast in the spring, joining others that have overwintered between North Carolina and Massachusetts Bay (Kraus et al. 1986, Kenney et al. 2001). In most years right whales occur at high densities in the Great South Channel in May, feeding intensively on copepods (Kenney et al. 1995). They then disperse farther north and east to summer feeding grounds in the lower Bay of Fundy and on the Scotian Shelf. A portion of the population, however, is not regularly sampled there (through photo-identification or skin biopsy); approximately one-third of the animals do not visit the Bay of Fundy (Schaeff et al. 1993). Determining where these 'non-Fundy' whales feed during the summer is therefore a high priority for management.

Two sets of charts depicting 19th century whale distribution-one by Maury (1851a, 1852 et seq., 1853) and one by Townsend (1935) - have been used as standards for comparison with the modern distribution of sperm and right whales (Maury) and of sperm, right, bowhead Balaena mysticetus, and humpback whales (Townsend) (e.g. Bannister \& Mitchell 1980, Schevill \& Moore 1983, Reeves \& Mitchell 1986, Scarff 1986, 1991, Clapham et al. 2004, Reeves et al. 2004). The information on those charts was derived primarily from logbooks of American whaling voyages. The North Atlantic distribution of right whales is poorly represented on the charts, only 2 of which have any information on the subject. Maury (1853) denoted a large shaded area in middle latitudes west of the Azores as a right whale ground (approximately bounded by 34 to $43^{\circ} \mathrm{N}$ and 25 to $48^{\circ} \mathrm{W}$ ). This area, illustrated and discussed by Reeves \& Mitchell (1986) and Reeves (2001), has come to be known informally as 'Maury's Smear'. Although Reeves \& Mitchell (1986) acknowledged that they had 'no idea what the Maury distribution (on Maury 1853) represents', it is now clear that Maury's Smear was a simplified depiction derived from quantitative data shown on Maury (1852 et seq.). The recent documentation of long-distance offshore movements by right whales from the western North Atlantic population - to $52^{\circ} 43^{\prime} \mathrm{N}, 38^{\circ} 36^{\prime} \mathrm{W}$ (a mother and calf; Knowlton et al. 1992), approximately $38^{\circ} 30^{\prime} \mathrm{N}, 65^{\circ} 30^{\prime} \mathrm{W}$ (an adult male; Mate et al. 1997) and Norway (1 animal; Jacobsen et al. 2004) — lends some plausibility to Maury's Smear.

For the present study, we examined the aetiology of the North Atlantic right whale data on the Maury charts with the goal of resolving the uncertainty surrounding Maury's Smear. We hoped to clarify the value of pursuing field research in that region by assessing its potential as an additional right whale calving ground or a summer feeding ground for 'nonFundy' whales. Also, having noted previous errors on one of the Townsend (1935) charts, where humpback whales rather than right whales were shown to occur along a portion of the north-western coast of Africa (Reeves \& Mitchell 1990), we considered it important to test the reliability of Maury's data. This need was underlined by the study of Clapham et al. (2004), who pointed to major differences between Maury's (1852 et seq.) depiction of the distribution of North Pacific right whales Eubalaena japonica and the documented present-day distribution of that species.

\section{MATERIALS AND METHODS}

The 3 Maury whale charts (1851a, 1852 et seq., 1853) used in this study were produced as parts of a multiyear oceanographic study 'concerning navigation and the industrial pursuits of the sea' (Maury 1851c; see also Maury 1851b, 1854, 1855, 1858, Chatwin 1996). They were based on data extracted from whaling voyage logbooks, with the goal of showing 'when and where our whalemen have searched for whales; when and where they have found them; with what abundance; and whether in schools or alone' (Maury 1851c). The 1851 chart does not display any North Atlantic data (Reeves \& Mitchell 1986). The colour-coded 1853 chart (Fig. 1) entitled 'A Chart Showing the Favourite Resort of the Sperm and Right Whale' purports to illustrate the global distribution of right whales Eubalaena spp. and sperm whales. According to the caption, the chart was meant to show areas of sperm whale distribution in red shading, areas of right whale distribution in blue and areas where both species were present in purple. Visual inspection revealed that some areas have darker shading than others and that in some areas the blue and red shading was overlaid (e.g. east of the main Japanese islands), apparently intended to produce the purple shading. Although it is not always certain how one should interpret the colours and overlays, several offshore areas are clearly blue, indicating the occurrence of right whales. One of those is in the North Atlantic west of the Azores. Because the globe is split at $30^{\circ} \mathrm{W}$ on this chart, most of the area (Maury's Smear) occurs on the right-hand side while the remainder occurs on the left-hand side of the chart. Maury's Smear is of particular interest because it represents the only 'evidence' suggesting that right whales did have, and may still have, a far offshore distribution in the central North Atlantic.

Maury (1853) gave no indication of seasonality or of the relative amounts of whaling (search) effort in the various geographical areas. However, the caption of the 1853 chart states that it was based on Maury's (1852 et seq.) chart called 'The Whale Chart of the World' (Fig. 2). This latter chart displays quantitative data on both whale observations and searching effort in $5^{\circ}$ squares by month. The whale observations are 


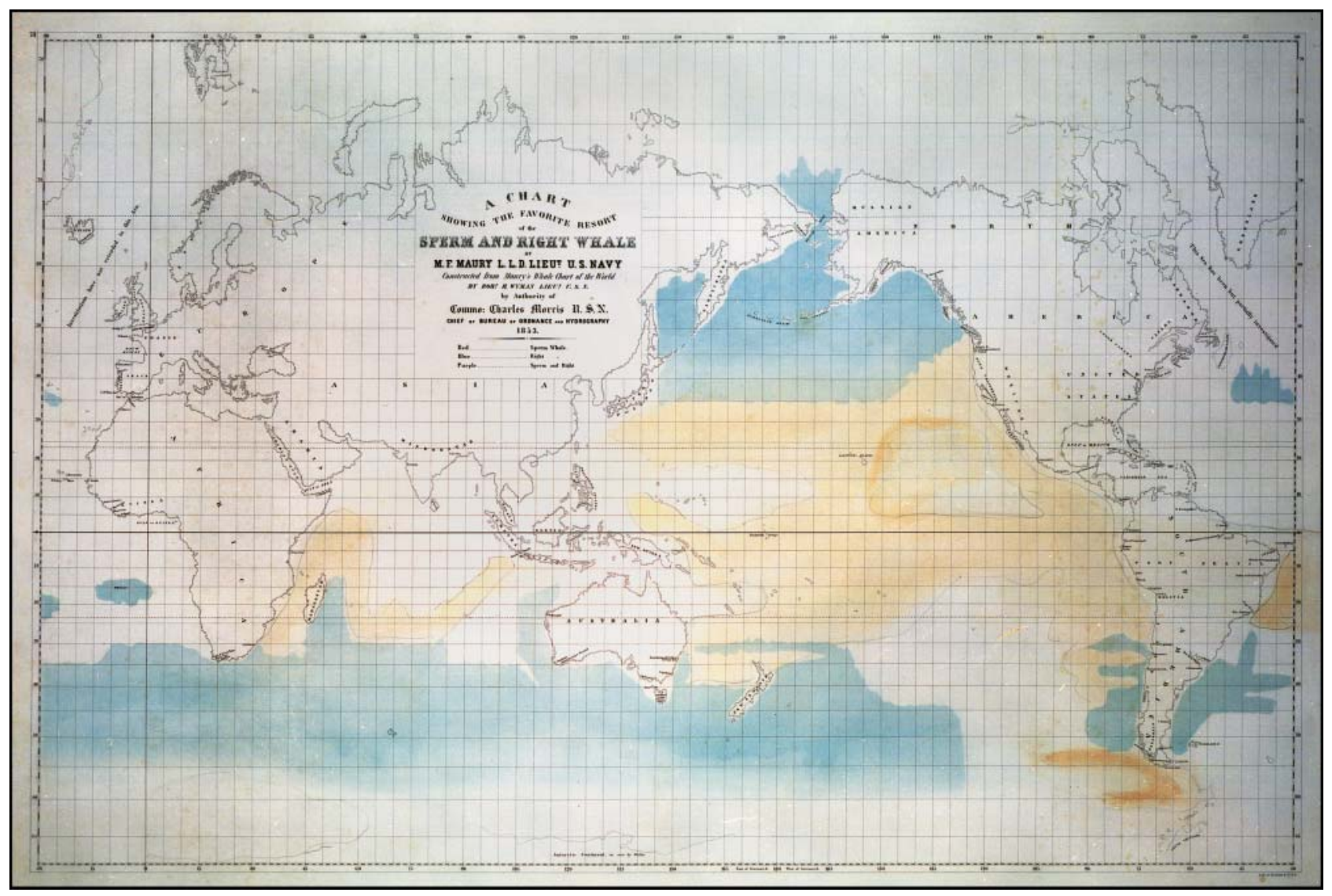

Fig. 1. 'A Chart Showing the Favourite Resort of the Sperm and Right Whale', 1853, by M. F. Maury, LLD. Lieut US Navy. 'Maury's Smear' is the blue-shaded area in the North Atlantic on the extreme right centre of the chart (note that it continues slightly at the extreme left centre of the chart)

expressed as the number of days during each month when 1 or more right (or sperm) whales were encountered; they encompass sightings, kills and struck/lost whales. Whaling effort is given as the number of days that vessels 'had fished' in the square (Maury 1852 et seq., 'Explanation' text on chart; see also Maury $1851 \mathrm{~b}, \mathrm{c}$ ) with no consideration for weather, sea conditions or activities on board. Each $5^{\circ}$ square is divided horizontally into 12 sections corresponding to the months of December, January, ... November, and

Fig. 2. A portion of the North Atlantic on Maury's (1852 et seq.) 'Whale Chart of the World'. The chart was printed on 4 sheets, each covering a different quadrant of the globe. Sections of Sheets 1 and 3 have been combined here to cover the Atlantic Ocean from the Equator north to $45^{\circ} \mathrm{N}$. The ten $5^{\circ}$ squares that include days on which right whales are shown as having been seen are highlighted and numbered for reference the numerical data are represented by the height of a colour-coded line above the base line of latitude for each square (Fig. 3). We compared the 1852 and 1853

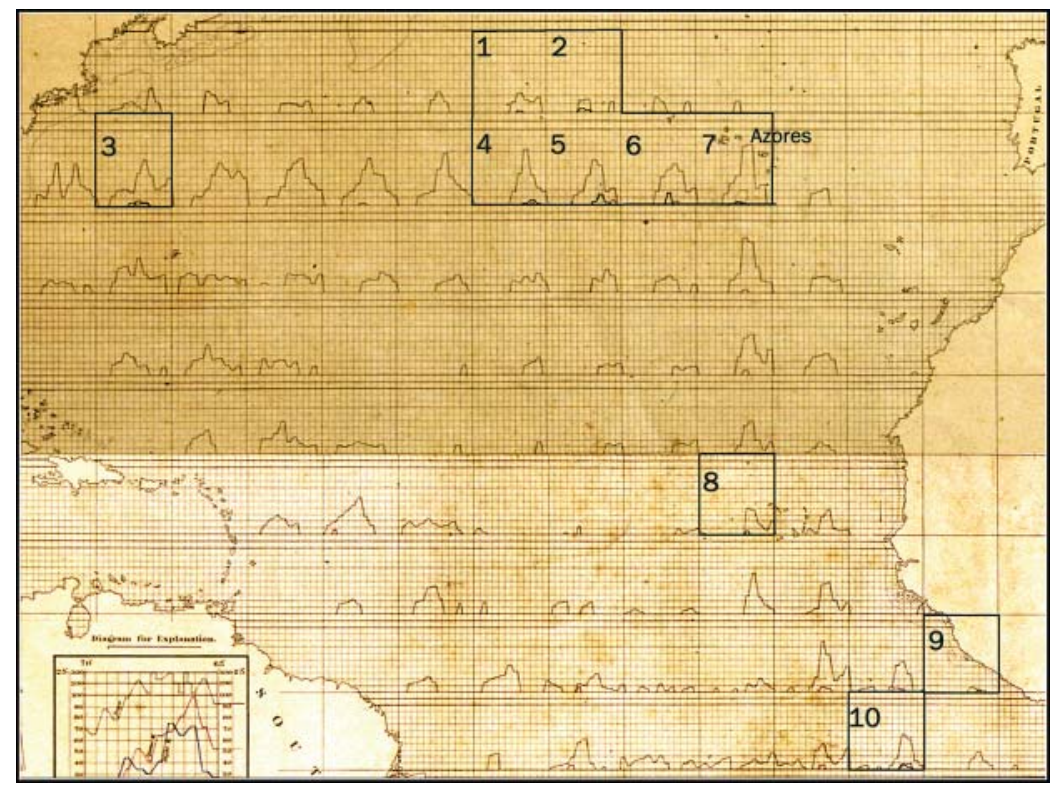




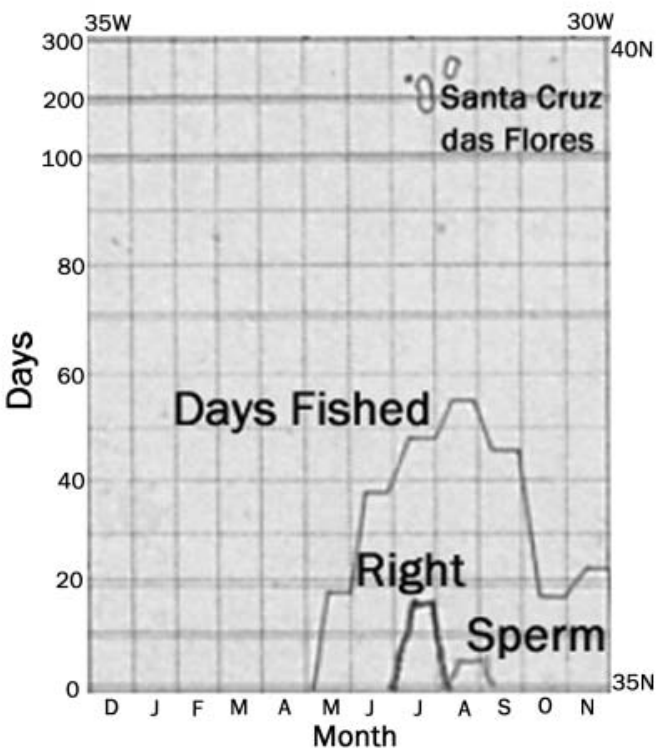

Fig. 3. The $5^{\circ}$ square labelled No. 6 on Fig. 2, from Maury's (1852 et seq.) 'Whale Chart of the World', showing the number of days searched by whaling ships in that area ('Days Fished') and the numbers of days on which right and sperm whales were seen, all by month

charts visually and extracted from the North Atlantic portion of the 1852 chart the numbers of days on which right whales were sighted, by month and by $5^{\circ}$ square.

The 1852 chart was based on data extracted from whaling voyage logbooks and recorded on data sheets labelled 'Maury Abstracts' (see Maury 1851b, 1854, 1858). The abstract of a given voyage includes daily records of vessel location, weather, presence of whales and other observations. Some of the abstracts were completed at sea but most were completed ashore using the logbook or some other record of events on board.

We located 88 microfilms containing the 355 volumes of Maury Abstracts known to be extant (representing roughly $2 / 3$ of the 533 volumes prepared), including merchant, naval and whaling voyages (Gibbs 1981). The microfilms include an index of ship names and voyage characteristics (e.g. dates). We also located computer data files containing daily position and weather observations that had been extracted from all but 1 microfilm, that being of poor quality. ${ }^{1}$ Using the index, we identified abstracts from more than 670 whaling voyages between 1797 and 1855. The index sometimes included multiple whaling voyages in one entry, so some whaling voyages could not be distinguished easily. We used the daily position data files and the microfilm index to identify abstracts with data from the North Atlantic. Primary

\footnotetext{
${ }^{1}$ NOAA (1998) The Maury Collection: global ship observations 1792-1910. National Oceanic and Atmospheric Administration, National Climate Data Center, Asheville, North Carolina, USA
}

source documents for individual whaling voyages that are in public archives were identified from Sherman et al. (1986), Lund (2001) and the records held by individual institutions. We linked information from the Maury Abstracts on vessel name, home port and year with data from roughly 15000 American open-boat whaling voyages sailing between 1770 and 1924, assembled from Starbuck (1878), Townsend (1935), Hegarty (1959), Davis et al. (1997) and Lund (2001). Using those linked data, we determined the existence and location of publicly available primary source documents (usually voyage logbooks) corresponding to Maury Abstracts that contained North Atlantic data. Even though all American voyages during this period departed from the New England region, the North Atlantic portions of many voyages were not included in the Maury Abstracts, and we do not know the reason for this omission.

We made several comparisons among the charts, abstracts and primary source documents. First, we compared the North Atlantic right whale distribution on Maury's 1853 chart to the data on right whale sightings on his 1852 chart. Second, we compiled all records of 'whale(s)' and 'right whale(s)' from the North Atlantic found in the Maury Abstracts and compared these to the geographical distribution indicated for right whales on the 2 charts. Finally, to validate species identifications, we compared the entries in the Maury Abstracts to corresponding entries in whaling voyage logbooks.

\section{RESULTS}

\section{North Atlantic right whale data on the Maury Charts}

Right whale observations are shown in ten $5^{\circ}$ squares on the North Atlantic portion of Maury's 1852 chart. Each of these squares was assigned an identifier number as shown in Fig. 2. For each square, we visually estimated the number of days, by month, when right whales were observed (Table 1). The number of right whale days, which totalled 113, increased from May to July and then declined in August, September and October. No observations were indicated for the months of November to April. Six of the squares shown on Fig. 2 (Nos. 1, 2, 4, 5, 6 and 7 in the rectangle bounded by 25 to $45^{\circ} \mathrm{W}$ and 35 to $45^{\circ} \mathrm{N}$ ) correspond to Maury's Smear on the 1853 chart while the other 4 squares are widely scattered in areas not highlighted as right whale grounds on the 1853 chart.

\section{North Atlantic right whale data in the Maury Abstracts}

We examined 243 abstracts with North Atlantic data. Two individuals are known to have prepared 207 
Table 1. Number of days on which North Atlantic right whales were seen in the ten $5^{\circ}$ squares (as numbered in Fig. 2) based on counts taken directly from Maury's (1852 et seq.) 'Whale Chart of the World'

\begin{tabular}{|c|c|c|c|c|c|c|}
\hline Square & May & Jun & Jul & Aug & Sep & Oct \\
\hline 1 & & & 2 & & & \\
\hline 2 & 4 & 2 & & & & \\
\hline 3 & 5 & 3 & 5 & & & \\
\hline 4 & & & & 3 & 7 & 3 \\
\hline 5 & & & 4 & 14 & 3 & \\
\hline 6 & 2 & 5 & 20 & & & \\
\hline 7 & 3 & 5 & 2 & & & \\
\hline 8 & & & 7 & & & \\
\hline 9 & & & & 3 & & \\
\hline 10 & & & & 9 & 2 & \\
\hline Total & 14 & 15 & 40 & 29 & 12 & 3 \\
\hline
\end{tabular}

of them: George Manning and Daniel McKenzie (Table 2). Thirty-one other abstracts were completed at sea, apparently by the ship's master or mate, and it was not possible to determine who prepared the remaining 5. None of these 36 latter abstracts contained specific reference to right whales in the North Atlantic.

Whale observations were recorded in the abstracts prepared by Manning and McKenzie in several ways. The simplest was for the species to be entered directly as 'right whale', 'right whales', 'sp. whale' or 'sp. whales'. In many instances, however, only the term 'whale' or 'whales' was entered. Reeves \& Mitchell (1986, p. 239) dismissed the Maury Abstracts as nonuseful after examining approximately 40 of them, stating: "Many of the abstracts note only that "whales" were sighted or killed, giving no information about which species was involved'. During the present study, however, the following statement by Manning was found associated with the abstracts: '... the word "whale" is to be understood as meaning 1 right whale and abbreviated thus - " -. "Whales" or "do" means more than 1 and when they are sperm whales "Sp" is prefixed'. Therefore, it would seem that references by Manning to 'whale' or 'whales' should be interpreted as referring to right whales.

Direct examination of the abstracts containing North Atlantic data revealed that 60 (56 prepared by Manning and 4 by McKenzie) of them included North Atlantic references to 'whale' or 'whales'. In addition, McKenzie recorded 'right whales' at $7^{\circ} 36^{\prime} \mathrm{N}, 18^{\circ} 12^{\prime} \mathrm{W}$ on 13 November 1838 during the voyage of the 'Garland' of New Bedford (1838-1840) (Table 2). This sighting was west of square No. 9 and north of square No. 10 in Fig. 2, well outside Maury's Smear.

In the above-mentioned 56 Manning abstracts, 78 instances of unspecified 'whale(s)' were recorded for the North Atlantic (Fig. 4), compared to $113 \mathrm{~d}$ with
Table 2. Number of Maury Abstracts that include North Atlantic observations prepared by McKenzie and by Manning, showing whether they contain entries referring to unspecified 'whales' or 'right whales' and whether they are represented by primary source material that was available for inspection

\begin{tabular}{|lcc|}
\hline & McKenzie & Manning \\
\hline Abstracts & 62 & 145 \\
With unspecified 'whales' & 4 & 56 \\
With 'right whales' & 1 & 0 \\
Primary sources available & 0 & 14 \\
\hline
\end{tabular}

'right whale' observations shown on the 1852 chart (Fig. 2). The 78 'whale' observations spanned all 12 mo rather than only from May to October (Table 3). Further, the positions for many of these sightings occurred outside areas containing right whale observations as shown on Maury's 1852 chart (compare Figs. 2 \& 4).

\section{North Atlantic right whale data in primary sources}

We located primary source documents for 14 of the Maury Abstracts with supposed right whale observations in the North Atlantic (i.e. 'whale' or 'whales' or 'right whales' appeared in the abstract). Those voyages, all originating in the more westerly ports of Sag Harbor, New London and Cold Spring Harbor, were abstracted by Manning, who worked out of New York

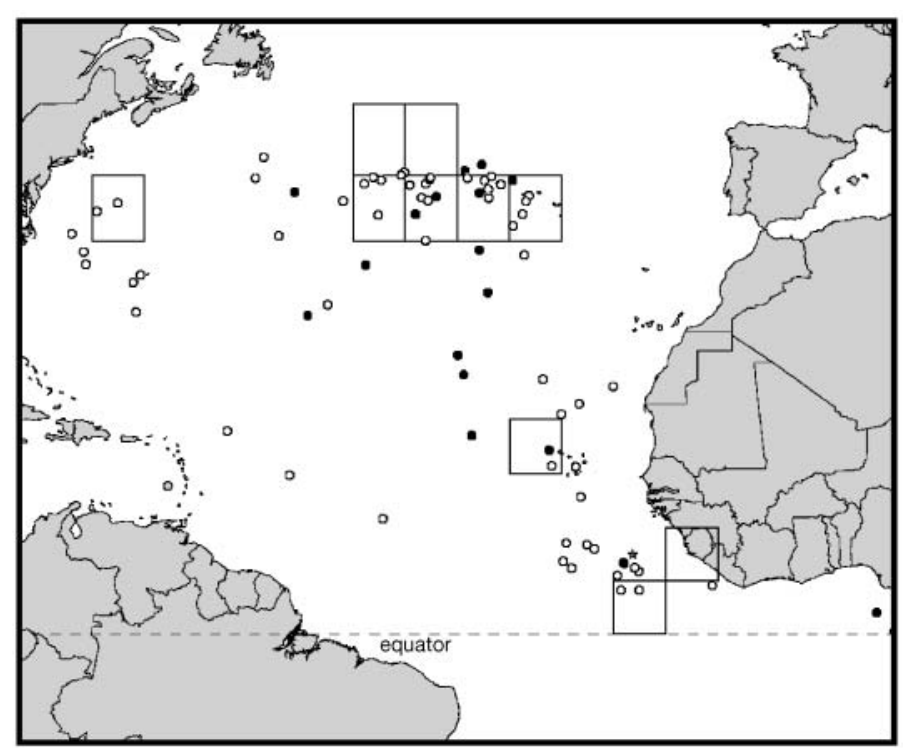

Fig. 4. Locations of the 78 sighting days of unspecified 'whale(s)' and 1 of 'right whales' in the North Atlantic, from Maury Abstracts (open and solid circles, plus the star), shown in relation to the $5^{\circ}$ squares illustrated in Fig. 2. The 17 sighting days that were compared to logbook entries are shown with solid circles; the one that was specifically denoted as 'right whales' is shown with a star 
Table 3. Monthly distribution of 78 whale observations in the North Atlantic recorded as 'whale(s)' in Maury Abstracts (Fig. 4). The $5^{\circ}$ squares are numbered as shown in Fig. 2

\begin{tabular}{|c|c|c|c|c|c|c|c|c|c|c|c|c|}
\hline Square & Jan & Feb & Mar & Apr & May & Jun & Jul & Aug & Sep & Oct & Nov & Dec \\
\hline 1 & & & & & & 1 & & & & & & \\
\hline \multicolumn{13}{|l|}{2} \\
\hline 3 & & & & & & 2 & & & & & & \\
\hline 4 & & & & 1 & & & 1 & 2 & & & & 1 \\
\hline 5 & & 1 & & & & & 6 & & 1 & & & 1 \\
\hline 6 & & & & & 1 & & 3 & 2 & 1 & & & \\
\hline 7 & & & & & & 1 & 3 & 1 & & & & \\
\hline 8 & & & & & & & & 1 & & & 1 & \\
\hline \multicolumn{13}{|l|}{9} \\
\hline 10 & 1 & & & & & & & 1 & & & & \\
\hline Outside & 2 & 1 & 2 & 3 & 5 & 1 & 11 & 8 & 4 & 2 & 2 & 4 \\
\hline Total & 3 & 2 & 2 & 4 & 6 & 5 & 24 & 15 & 6 & 2 & 3 & 6 \\
\hline
\end{tabular}

Table 4. Primary source documents used to test the accuracy of species identifications in Maury Abstracts, showing vessel name, port, years of the voyage and information about the documentation, including publicly accessible archive where held, type of document and our confidence that this was the document actually used by Manning to prepare the abstract. KWM coll.: Kendall Whaling Museum collection NBW coll.: New Bedford Whaling Museum collection

\begin{tabular}{|c|c|c|c|c|c|c|}
\hline \multirow[t]{2}{*}{ Source } & \multicolumn{3}{|c|}{-Voyage } & \multirow{2}{*}{\multicolumn{2}{|c|}{$\begin{array}{r}\text { Details of source material }- \\
\text { Lescription }\end{array}$}} & \multirow[b]{2}{*}{ Confidence } \\
\hline & Vessel & Port & Years & & & \\
\hline 1 & Neptune & Sag Harbor & $1834-35$ & $\begin{array}{l}\text { Kendall Institute (KWM coll.), } \\
\text { New Bedford, MA }\end{array}$ & $\begin{array}{l}\text { End of voyage } \\
\text { accounts list }\end{array}$ & None \\
\hline 2 & Neptune & Sag Harbor & $1835-36$ & $\begin{array}{l}\text { Rogers Mem. Lib., } \\
\text { Southampton, NY }\end{array}$ & $\begin{array}{l}\text { Detailed logbook } \\
\text { kept by captain }\end{array}$ & High \\
\hline 3 & Acasta & Sag Harbor & $1830-31$ & $\begin{array}{l}\text { Kendall Institute (NBW coll.), } \\
\text { New Bedford, MA }\end{array}$ & Detailed logbook & High \\
\hline 5 & Argonaut & Sag Harbor & $1823-24$ & $\begin{array}{l}\text { Rogers Mem. Lib., } \\
\text { Southampton, NY }\end{array}$ & Detailed logbook & High \\
\hline 6 & Catherine & New London & $1843-45$ & $\begin{array}{l}\text { Mystic Seaport Museum, } \\
\text { Mystic, CT }\end{array}$ & $\begin{array}{l}\text { Journal, sporadic, } \\
\text { no positions }\end{array}$ & None \\
\hline 7 & Monmouth & Cold Spring Harbor & $1843-46$ & $\begin{array}{l}\text { Kendall Institute (KWM coll.), } \\
\text { New Bedford, MA }\end{array}$ & Incomplete logbook & Low \\
\hline 10 & Marcus & Sag Harbor & $1841-43$ & $\begin{array}{l}\text { Mystic Seaport Museum, } \\
\text { Mystic, CT }\end{array}$ & $\begin{array}{l}\text { Detailed logbook } \\
\text { kept by captain }\end{array}$ & Medium $^{b}$ \\
\hline 11 & Charleston & New London & $1844-47$ & $\begin{array}{l}\text { Kendall Institute (NBW coll.), } \\
\text { New Bedford, MA }\end{array}$ & $\begin{array}{l}\text { Typewritten journal } \\
\text { kept by 3rd mate }\end{array}$ & Low \\
\hline 12 & Josephine & Sag Harbor & $1843-46$ & $\begin{array}{l}\text { Kendall Institute (KWM coll.) } \\
\text { New Bedford, MA }\end{array}$ & $\begin{array}{l}\text { Journal, sporadic, } \\
\text { with positions }\end{array}$ & None \\
\hline 13 & Neptune & Sag Harbor & $1839-41$ & $\begin{array}{l}\text { Smithtown Lib., } \\
\text { Smithtown, NY }\end{array}$ & Logbook & Medium \\
\hline 14 & Monmouth & Cold Spring Harbor & $1843-46$ & $\begin{array}{l}\text { East Hampton Free Lib., } \\
\text { Easthampton, NY }\end{array}$ & Detailed logbook & Medium \\
\hline 15 & Neptune & Sag Harbor & $1834-35$ & $\begin{array}{l}\text { Rogers Mem. Lib., } \\
\text { Southampton, NY }\end{array}$ & $\begin{array}{l}\text { Detailed logbook } \\
\text { kept by captain }\end{array}$ & High \\
\hline
\end{tabular}


(Gibbs 1981). No primary source material could be located for any of the voyages with North Atlantic data abstracted by McKenzie, whose principal work site was New Bedford. Upon examining the available source material, we assessed the likelihood that a given document was the same one that had been used by Manning to prepare the corresponding voyage abstract (Confidence, Table 4).

\section{Tests of consistency}

We were able to test 17 (Table 5) of the 78 'whale' or 'whales' entries in the abstracts (Fig. 4) by comparing them with the entries for the same dates in the source documents (some of the 14 abstracts had multiple 'whale(s)' sightings). In each instance, we compared the geographical positions and other observations (e.g. weather, wind direction) recorded in the 2 matched sources (abstract on one hand, primary source on the other) to determine consistency and we noted the relevant text in the source document describing the whale observation (Table 5). For example, Fig. 5 shows for our second test (Table 5) the page in the abstract where 'whales' was recorded and Fig. 6 shows the corresponding logbook entry for that voyage (Source 2 , Table 4). In this instance, we judged that the voyage logbook was very likely the source document that Manning had used to prepare the abstract (Confi- dence: High, Table 4). The geographical and other data matched exactly between the abstract and the logbook but the test failed because the logbook entry indicated a sperm whale rather than a right whale. Of the 17 entries tested, 10 failed because they clearly did not refer to right whales. Of those 10 outcomes, we had high confidence in 7 and less confidence in 3 (Table 5). The remaining 7 tests were inconclusive because the source documents were relatively uninformative and therefore almost certainly were not the ones used by Manning to prepare the abstracts. These last 7 test cases are included here simply to demonstrate that all available primary source documents were considered in our analysis. None of our tests confirmed that 'whale(s)' were right whales and the 7 tests with conclusive outcomes were all negative, i.e. they confirmed that 'whale(s)' were not right whales. Four of those 7 involved sperm whales, 2 involved finbacks Balaenoptera spp. and 1 involved what was identified as either a sperm or a humpback whale (Table 5).

\section{DISCUSSION AND CONCLUSIONS}

All of the records that we were able to test by reference to primary source documents involved abstracts prepared by George Manning, one of Maury's 2 principal assistants. Contrary to the statement of intent by Manning, we found no evidence that

Table 5. Results of tests of accuracy of species identifications in Maury Abstracts. Sources in second column refer to Table 4. Failed outcome means abstract entry and 'logbook' entry were contradictory. Concordance indicates the degree to which geographical positions and dates agreed between the Maury Abstract and the 'logbook'

\begin{tabular}{|c|c|c|c|c|c|c|}
\hline Test & Source & $\begin{array}{l}\text { Date } \\
\text { (d/mo/yr) }\end{array}$ & 'Logbook' species description & Outcome & Confidence & Concordance \\
\hline 1 & 1,15 & $11 / 7 / 1834$ & 'Saw 2 or 3 sperm whales' & Failed & High & Position and date matched \\
\hline 2 & 2 & 19/7/1835 & 'Saw a sperm whale' & Failed & High & Position and date matched \\
\hline 3 & 3 & $18 / 7 / 1830$ & $\begin{array}{l}\text { 'Raised a shoal of sperm whales, } \\
\text { struck and killed 2' }\end{array}$ & Failed & High & Position and date matched \\
\hline 4 & 5 & $15 / 6 / 1823$ & 'Saw 2 sperm whales' & Failed & High & Position and date matched \\
\hline 5 & 7,14 & 2/11/1843 & 'Saw 1 finback' & Failed & High & Position and date matched \\
\hline 6 & 13 & 8/9/1839 & 'Saw a number of finbacks' & Failed & High & Position and date matched \\
\hline 7 & 10 & 7/1/1842 & 'Saw 1 sperm whale or humpback' & Failed & High & Position and date matched \\
\hline 8 & 12 & 31/7/1846 & 'Saw a shoal of sperm whales' & Failed & Medium & $\begin{array}{l}\text { Position was close and date } \\
\text { matched }\end{array}$ \\
\hline 9 & 11 & $10 / 7 / 1844$ & 'Sperm whale on our weather bow' & Failed & Low & $\begin{array}{l}\text { Position matched and date } \\
\text { was close }\end{array}$ \\
\hline 10 & 10 & $6 / 12 / 1841$ & No whale recorded ${ }^{\mathrm{a}}$ & Failed & Low & $\begin{array}{l}\text { Position did not match but } \\
\text { date did match }\end{array}$ \\
\hline 11 & 4 & 9/7/1832 & None & Inconclusive & None & No entry for date ${ }^{b}$ \\
\hline 12 & 6 & 9/10/1843 & None & Inconclusive & None & No entry for date \\
\hline 13 & 8 & 3/8/1843 & None & Inconclusive & None & No entry for date \\
\hline 14 & 9 & 19/11/1843 & None & Inconclusive & None & No entry for date \\
\hline 15 & 16 & $30 / 12 / 1843$ & None & Inconclusive & None & Entry for date but no position \\
\hline 16 & 16 & 31/12/1843 & None & Inconclusive & None & Entry for date but no position \\
\hline 17 & 16 & $3 / 1 / / 1844$ & None & Inconclusive & None & Entry for date but no position \\
\hline
\end{tabular}




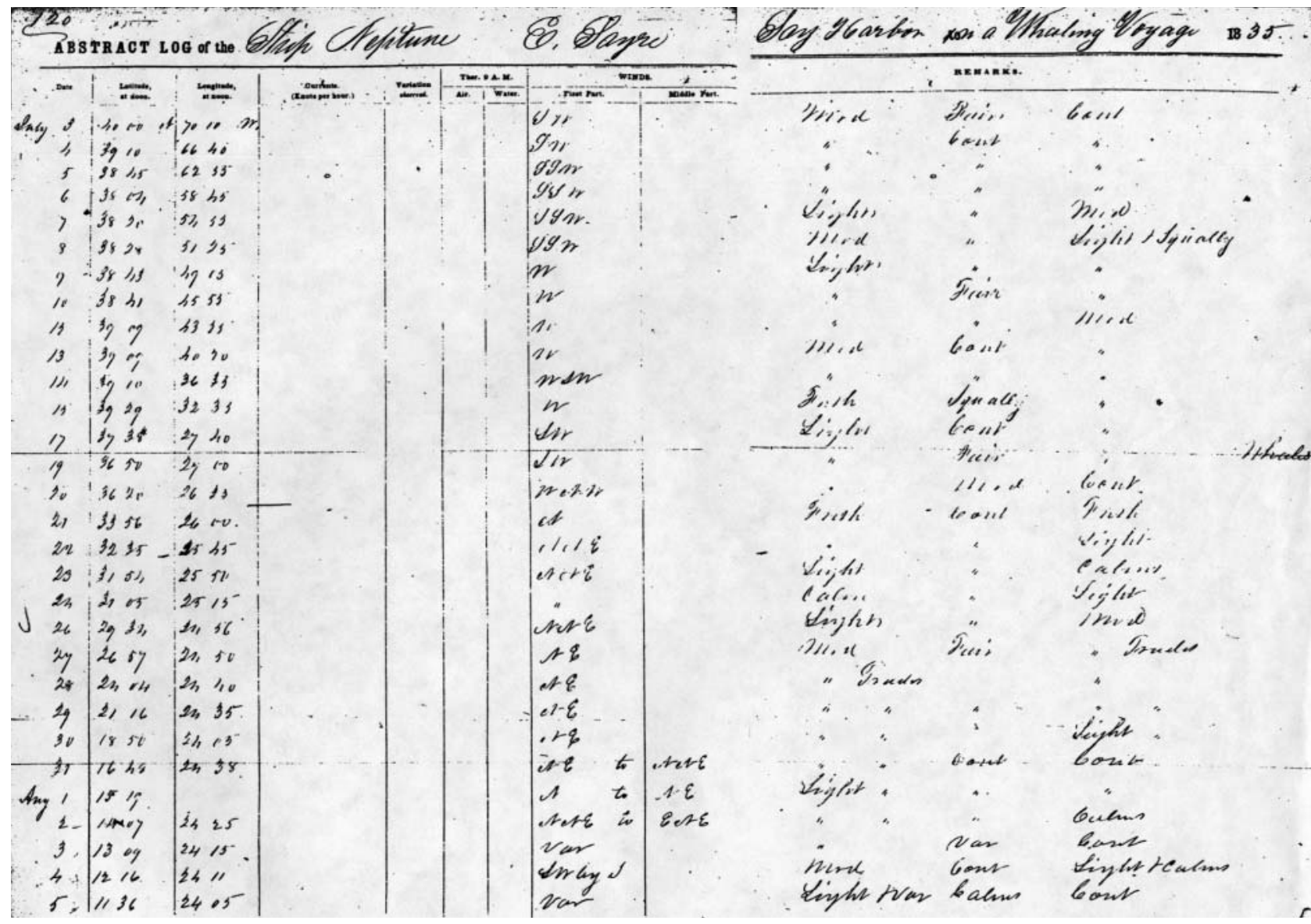

Fig. 5. Part of a page of the Maury Abstract of the voyage of the 'Neptune' of Sag Harbor, 1835-1836, showing that a whale was sighted on 19 July 1835 at $36^{\circ} 50^{\prime} \mathrm{N}, 27^{\circ} 00^{\prime} \mathrm{W}$. Weather conditions and wind direction are also indicated

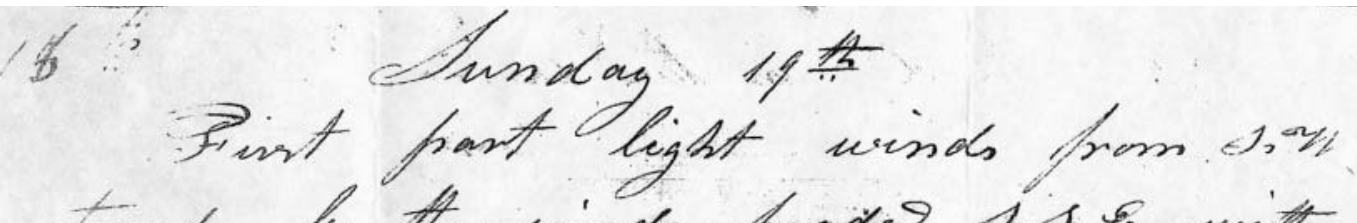

Heard ly the wind heades did. 8 weits ald rinwong soub sef

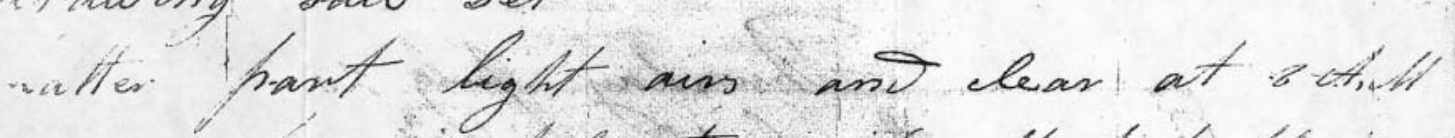

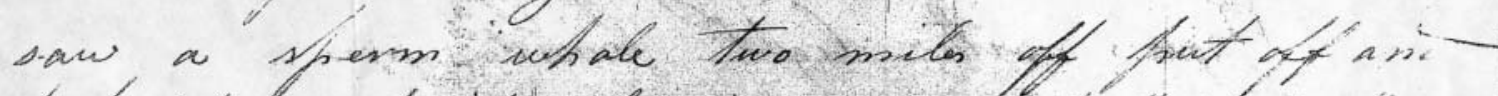

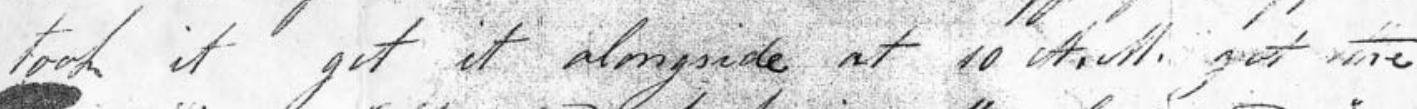

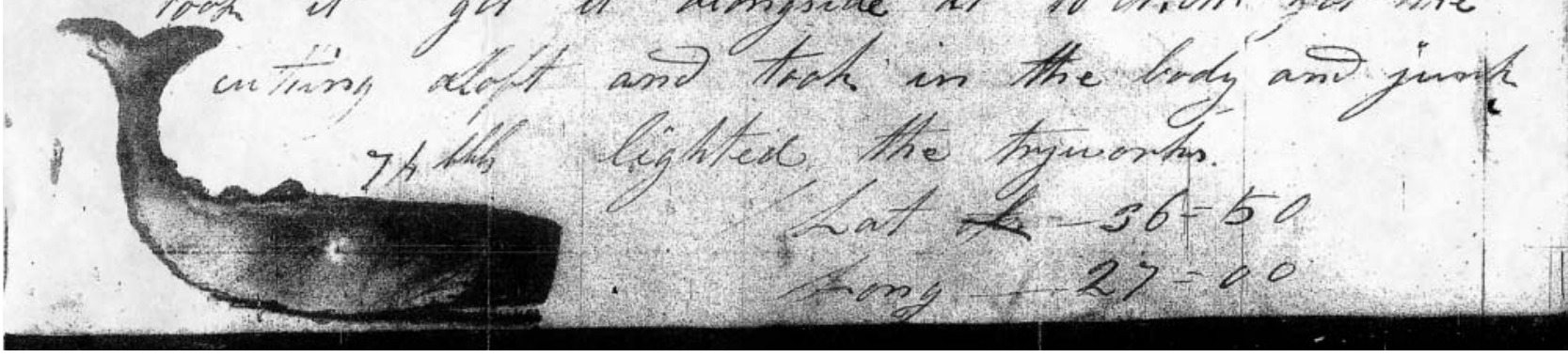

Fig. 6. Logbook entry for 19 July 1835 from the voyage of the 'Neptune' (see Fig. 5), showing that the whale seen on that date was a sperm whale, not a right whale 
sightings recorded as 'whale' or 'whales' in the North Atlantic were actually of right whales. We were unable to locate any primary source documents corresponding to abstracts with North Atlantic data prepared by the other abstractor, Daniel McKenzie. None of the evidence from this study gives credence to the putative offshore distribution of right whales in the central North Atlantic indicated on Maury's 1852 and 1853 charts. We conclude that there is no support in the extant Maury Abstracts for the belief that right whales occurred in Maury's Smear. Most, if not all, of the right whale occurrences in the North Atlantic shown on Maury's 1852 and 1853 charts appear to be based on faulty data extraction or transcription procedures.

Maury's Smear is therefore an unlikely alternative feeding ground for 'non-Fundy' right whales from the western North Atlantic. There are several more likely areas. A few whales have been observed recently during summer months in the north-western Gulf of St. Lawrence and along the south coast of Newfoundland (Lien et al. 1989) and farther eastward off southern Greenland, Iceland and Norway (Knowlton et al. 1992, Jacobsen et al. 2004). Satellite tracking has demonstrated long-distance movements from the lower Bay of Fundy to the north-western wall of the Gulf Stream $500 \mathrm{~km}$ offshore (in water $4200 \mathrm{~m}$ deep) (Mate et al. 1997, Slay \& Kraus 1998). Right whales were hunted to some extent by the Basques off northern Newfoundland and southern Labrador (Aguilar 1986, Cumbaa 1986) and later by American whalers in those same areas as well as along the eastern edges of the Grand Banks (Reeves \& Mitchell 1986). A specific area east and south-east of the southern tip of Greenland known as the Cape Farewell Ground (approximately 60 to $62^{\circ} \mathrm{N}, 33$ to $35^{\circ} \mathrm{W}$ ) was visited by American whaleships between 1868 and 1898 with the explicit intention of finding right whales (Reeves \& Mitchell 1986), and a survey of that area in July 2003 resulted in a sighting of 1 whale (M. W. Brown pers. comm.). Those areas to the north and north-east of the Bay of Fundy/Scotian Shelf region would seem to be more likely alternative feeding grounds for the western North Atlantic right whale population than the far offshore waters of the central North Atlantic.

In addition to finding some 'whale' entries in the Maury Abstracts that correspond with right whale positions ( $5^{\circ}$ squares) and times (months) shown on the 1852 chart, we found numerous entries that either fell outside the right whale squares or were in months other than those indicated for right whale observations on the chart (Fig. 4, Table 3). Such records suggest that only a subset of the whale encounters reported in the Maury Abstracts was transferred to the 1852 chart but the reason for this discrepancy is unclear.
Maury (1851b,c, 1858) described the procedures used to create his charts (see also Chatwin 1996). Most of the abstracts of whaling voyages were prepared by McKenzie and Manning beginning in the 1840s. The abstracts were sent to the Ordnance and Hydrographic Bureau in Washington, DC, where they were transcribed onto tables by $5^{\circ}$ square and by month (Maury 1858, Plate IX) by a series of young naval officers between 1847 and 1851. It was not until 1851 that one of these officers (A. C. Jackson) remained at his post long enough to complete the transcription and prepare the charts. The separation (spatial and temporal, if not also in terms of background and training) between those who prepared the abstracts and those who prepared the charts would have allowed ample scope for misinterpretations. For example, Manning's explanation of his code for right whales (quoted above) appears in the 35th of his 46 known volumes of abstracts and all of our conclusive tests of Manning's data involved abstracts in earlier volumes. Although such an explanatory note in one of the first 34 volumes would have been easy for us to miss, as did Reeves \& Mitchell (1986; see above), it is also possible that Manning's explanation in the 35th volume represented a change in his abstracting procedures. If that were the case, Jackson easily could have applied the explanation incorrectly when he transcribed the earlier abstracts. Further, some of the Maury Abstracts bear the annotation 'Ex'd for whales', signed by A. C. Jackson. In those abstracts, some but not all of the sightings are marked with a horizontal line. If such a line was Jackson's way of indicating that he had transcribed that sighting, then sightings not so marked could be the ones that we noted in the abstracts but were not represented on the 1852 chart. However, the locations of marked sightings fell both inside and outside the ten $5^{\circ}$ squares with right whale sighting days shown on the chart. Finally, we found proportionally few sightings in the abstracts that matched the areas and months of the right whale sighting days indicated on the 1852 chart. One explanation could be that a disproportionately large number of abstracts of whaling voyages (as opposed to merchant and naval voyages) are missing from the available microfilm collections.

In addition to discrediting Maury's Smear as a major concentration area for North Atlantic right whales, our results raise questions about the reliability of Maury's charts in other areas of the world's oceans and about the possibility that similar errors have been made in his depictions of the distributions of sperm whales, southern right whales Eubalaena australis and North Pacific right whales. This is important because the historical seasonal and spatial distributions of those species, and of American open-boat whaling activity, have frequently been inferred from secondary sources such as 
the Maury and Townsend charts rather than directly from whaling logbooks or other primary source documents. The faulty data extraction or transcription procedures documented for the Maury material (above) and at least occasionally for the Townsend charts (Reeves \& Mitchell 1990) have the potential to mislead biologists and resource managers. Although the limited scope of the present study precluded extensive evaluation of either Maury's sperm whale data from the North Atlantic or his right whale data from areas outside the North Atlantic, we found several examples where abstract entries referring to 'whales' or 'sp. whales' in the Southern Hemisphere were consistent with logbook entries referring to right whales and sperm whales, respectively. Further validation of both the Maury and Townsend charts is clearly warranted.

Our results may have additional implications. Although Maury has been described as a pioneer in oceanography, the editor of his book 'The Physical Geography of the Sea' (Maury 1963, p. ix) noted that when scientists 'have had the occasion to examine particular points in Maury's exposition' they have found shortcomings. However, shortcomings identified have not extended to the basic level of data extraction and transcription. For example, Bannister \& Mitchell (1980, p. 230) cited critiques of Maury's work in general but concluded that the criticisms did 'not reflect on the accuracy or interpretation of Maury's whale data'. Scarff (1991, p. 470) rigorously evaluated potential biases arising from his own efforts to tabulate and analyse North Pacific right whale data from Maury's charts but acknowledged that he was unable to 'resolve all questions of the accuracy of the transcriptions of data from the logbooks to abstracts, to the printed charts and thence to our [sic] tabulations'. Neither Bannister \& Mitchell (1980) nor Scarff (1991) attempted to test Maury's whale data directly against primary sources as we have done in the present instance.

Tests similar to those reported here could be undertaken for sperm whales and for right whales in other ocean basins simply by comparing data in the Maury Abstracts to data in primary sources. Such studies are likely to be more robust than our tests in the North Atlantic, where at least 2 factors conspired to limit the opportunities for comparisons. First, for unknown reasons many of the Maury Abstracts do not include any entries for days when ships were in the North Atlantic, even though almost all voyages at least transited it and many of those with a primary destination in some other ocean basin involved at least casual attempts to catch whales in the North Atlantic during either the outbound or inbound portion of the voyage. Second, we were able to locate primary source documents for only 14 of the 207 Maury Abstracts known to contain North Atlantic data, even though such documents are avail- able for more than $40 \%$ of the total whaling voyages covered by abstracts. The reasons for this poor success rate at finding primary source documents with which to validate North Atlantic data are, like so many aspects of Maury's monumental oceanographic inquiry (Chatwin 1996), not entirely clear.

Acknowledgements. Financial support for much of this work was provided by the National Oceanic and Atmospheric Administration through its National Marine Fisheries Service and its Office of Ocean Exploration, and by the Alfred E. Sloan Foundation's Census of Marine Life. We are indebted to the institutions holding the whaling voyage logbooks, especially the Kendall Institute of the New Bedford Whaling Museum in New Bedford, Massachusetts; the Blunt White Library, Mystic Seaport, Mystic, Connecticut; the Providence Public Library, Providence, Rhode Island; the Rogers Memorial Library, Southampton, New York; the Connecticut State Library, Hartford; the Smithtown Library, Smithtown, New York; and the East Hampton Free Library, Easthampton, New York. We thank E. Eastin, D. Dayton, C. Ball and L. Khosla for their help with logbook research. We are also grateful for the support of staff members at the Kendall Institute, especially M. Dyer, S. Frank and L. Pereira, who provided efficient access to the valuable materials in their care and functioned as collaborators on projects such as this one, freely sharing their considerable knowledge and experience of whaling history. M. Lapides, also of the Kendall Institute, contributed by providing expert photographic and digital work in reproducing the charts for us. P. Slattery kindly gave us permission to reproduce his rare original copy of the 1853 Maury chart. Finally, we acknowledge several colleagues who allowed us access to their data: J. Lund, L. Davis, K. Gleiter, J. Bannister, H. Whitehead and P. L. Hope. Scott Baker provided a particularly insightful review of the manuscript, and we thank him for the constructive criticism.

\section{LITERATURE CITED}

Aguilar A (1986) A review of old Basque whaling and its effect on the right whales (Eubalaena glacialis) of the North Atlantic. Rep Int Whal Comm (Spec Issue) 10:191-199

Bannister J, Mitchell E (1980) North Pacific sperm whale stock identity: distributional evidence from Maury and Townsend charts. Rep Int Whal Comm (Spec Issue) 2:219-230

Brown MW, Brault S, Hamilton PK, Kenney RD and 5 others (2001) Sighting heterogeneity of right whales in the western North Atlantic: 1980-1992. J Cetacean Res Manag (Spec Issue) 2:245-260

Brown SG (1986) Twentieth-century records of right whales (Eubalaena glacialis) in the northeast Atlantic Ocean. Rep Int Whal Comm (Spec Issue) 10:121-127

Chatwin D (1996) The whale charts produced by Matthew Fontaine Maury. The Globe, J Aust Map Circle 44:59-67

Clapham PJ, Good C, Quinn, SE, Reeves RR, Scarff, JE, Brownell RL Jr (2004) Distribution of North Pacific right whales (Eubalaena japonica) as shown by 19th and 20th century whaling catch and sighting records. J Cetacean Res Manag 6:1-6

Cumbaa SL (1986) Archaeological evidence of the 16th century Basque right whale fishery in Labrador. Rep Int Whal Comm (Spec Issue) 10:187-190

Davis LE, Gallman RE, Gleiter K (1997) In pursuit of leviathan. Technology, institutions, productivity, and profits 
in American whaling, 1816-1906. University of Chicago Press, Chicago, IL

Gibbs SL (1981) The Maury Abstract logs 1796-1861, index and supplement. National Archives Microfilm Publication M1160. National Archives and Records Service, General Services Administration, Washington, DC

Hegarty RB (1959) Returns of whaling vessels sailing from American ports. A continuation of Alexander Starbuck's 'history of the American whale fishery' 1876-1928. New Bedford Whaling Museum, New Bedford, MA

Jacobsen KO, Marx M, Øien N (2004) Two-way trans-Atlantic migration of a North Atlantic right whale (Eubalaena glacialis). Mar Mamm Sci 20:161-166

Katona SK, Kraus SD (1999) Efforts to conserve the North Atlantic right whale. In: Twiss JR Jr, Reeves RR (eds) Conservation and management of marine mammals. Smithsonian Institution Press, Washington, DC, p 311-331

Kenney RD, Winn HE, Macaulay MC (1995) Cetaceans in the Great South Channel, 1979-1989: right whale (Eubalaena glacialis). Cont Shelf Res 15:385-414

Kenney RD, Mayo CA, Winn HE (2001) Migration and foraging strategies at varying spatial scales in western North Atlantic right whales: a review of hypotheses. J Cetacean Res Manag (Spec Issue) 2:251-260

Knowlton AR, Sigurjónsson J, Ciano JN, Kraus SD (1992) Long-distance movements of North Atlantic right whales (Eubalaena glacialis). Mar Mamm Sci 8:397-405

Kraus SD, Prescott JH, Knowlton AR, Stone GS (1986) Migration and calving of right whales (Eubalaena glacialis) in the western North Atlantic. Rep Int Whal Comm (Spec Issue) 10:139-144

Lien J, Sears R, Stenson GB, Jones PW, Ni IH (1989) Right whale, Eubalaena glacialis, sightings in waters off Newfoundland and Labrador and the Gulf of St. Lawrence, 1978-1987. Can Field Nat 103:91-93

Lund JN (2001) Whaling masters and whaling voyages sailing from American ports: a compilation of sources. New Bedford Whaling Museum, New Bedford, MA

Mate BR, Nieukirk SL, Kraus SD (1997) Satellite-monitored movements of the northern right whale. J Wildl Manag 61: 1393-1405

Maury MF (1851a) Whale chart (preliminary sketch), Series F. National Observatory, Washington, DC, 1 sheet

Maury MF (1851b) Explanations and sailing directions to accompany the wind and current charts, 3rd edn. C Alexander, Printer, Washington, DC

Maury MF (1851c) Important notice to whalemen. Hunts Merchants' Mag 24:773-777

Maury MF (1852 et seq.) Whale chart of the world (The wind and current charts), Series F. Washington, DC, 4 sheets: No. 1 (North Atlantic, NE Pacific) 1852, No. 2 (NW Pacific) no date, No. 3 (S Atlantic, SE Pacific) no date, No. 4 (SW Pacific, Indian Ocean) no date

Maury MF (1853) A chart showing the favourite resort of the sperm and right whale by MF Maury, LLD Lieut US Navy. Constructed from Maury's whale chart of the world by Robt H Wyman, Lieut USN by Authority of Commo Charles Morris USN Chief of Bureau of Ordnance and Hydrography, Washington, DC, 1 sheet

Maury MF (1854) Explanations and sailing directions to accompany the wind and current charts, 6th edn. EC \& J Biddle, Philadelphia, PA

Maury MF (1855) The physical geography of the sea. Harper \& Bros, New York

Maury MF (1858) Explanations and sailing directions to accompany the wind and current charts, 8th edn. Wm A Harris, Washington, DC

Maury MF (1963) The physical geography of the sea. Harvard University Press, Cambridge, MA

Notarbartolo di Sciara G, Politi E, Bayed A, Beaubrun PC, Knowlton A (1998) A winter cetacean survey off southern Morocco, with a special emphasis on right whales. Rep Int Whal Comm 48:547-550

Reeves RR (2001) Overview of catch history, historic abundance and distribution of right whales in the western North Atlantic and in Cintra Bay, West Africa. J Cetacean Res Manag (Spec Issue) 2:187-192

Reeves RR, Kenney RD (2003) Baleen whales: right whales and allies Eubalaena spp. In: Feldhamer GA, Thompson BC, Chapman JA (eds) Wild mammals of North America: biology, management, and conservation, 2nd edn. Johns Hopkins University Press, Baltimore, MD, p 425-463

Reeves RR, Mitchell E (1986) American pelagic whaling for right whales in the North Atlantic. Rep Int Whal Comm (Spec Issue) 10:221-254

Reeves RR, Mitchell E (1988) History of whaling in and near North Carolina. NOAA Tech Rep NMFS 65:1-28

Reeves RR, Mitchell E (1990) Right whales, not humpbacks, taken in Cintra Bay. Am Neptune 50:119-126

Reeves RR, Smith TD, Josephson E, Woolmer G (2004) Historical observations of humpback and blue whales in the North Atlantic Ocean: clues to migratory routes and possibly additional feeding grounds. Mar Mamm Sci 20: $774-786$

Scarff JE (1986) Historic and present distribution of the right whale (Eubalaena glacialis) in the eastern North Pacific south of $50^{\circ} \mathrm{N}$ and east of $180^{\circ} \mathrm{W}$. Rep Int Whal Comm (Spec Issue) 10:43-63

Scarff JE (1991) Historic distribution and abundance of the right whale (Eubalaena glacialis) in the North Pacific, Bering Sea, Sea of Okhotsk and Sea of Japan from the Maury whale charts. Rep Int Whal Comm 41:467-489

Schaeff CM, Kraus SD, Brown MW, White BN (1993) Assessment of the population structure of western North Atlantic right whales (Eubalaena glacialis) based on sighting and mtDNA data. Can J Zool 71:339-345

Schevill WE (1959) Return of the right whale to New England waters. J Mamm 40:639

Schevill WE, Moore KE (1983) Townsend's unmapped North Atlantic right whales (Eubalaena glacialis). Breviora 476: $1-8$

Schevill WE, Watkins WA, Moore KE (1986) Status of Eubalaena glacialis off Cape Cod. Rep Int Whal Comm (Spec Issue) 10:79-82

Sherman SC, Downey JM, Adams VM, Pasternack H (1986) Whaling logbooks and journals 1613-1927: an inventory of manuscript records in public collections. Garland, New York

Slay CK, Kraus SD (1998) Right whale tagging in the North Atlantic. Mar Technol Soc J 32:102-103

Starbuck A (1878) History of the American whale fishery from its earliest inception to the year 1876. Reprinted 1964 by Argosy-Antiquarian, New York (includes preface by SC Sherman and the Maury 1851 chart as endpiece)

Townsend $\mathrm{CH}$ (1935) The distribution of certain whales as shown by logbook records of American whaleships. Zoologica 19:1-50 (4 charts)

Watkins WA, Schevill WE (1983) Observations of right whales (Eubalaena glacialis) in Cape Cod waters. Fish Bull 80: 875-880

Submitted: February 10, 2004; Accepted: May 13, 2004

Proofs received from author(s): October 26, 2004 